\title{
Walnut growth and soil quality after inoculating soil containing rock phosphate with phosphate-solubilizing bacteria
}

\author{
Xuan Yu ${ }^{\mathrm{a}, \mathrm{b}}, \mathrm{Xu} \mathrm{Liu}{ }^{\mathrm{c}, *}$, Tian-hui Zhu ${ }^{\mathrm{b}}$ \\ a College of Forestry, Northwest A\&F University, Yangling, 712100, Shaanxi, China \\ ${ }^{b}$ College of Forestry, Sichuan Agricultural University, Yaan 625014, Sichuan, China \\ c College of Enology, Northwest A\&F University, Yangling 712100, Shaanxi, China \\ ${ }^{*}$ Corresponding author, e-mail: yx_9806@126.com
}

Received 9 Apr 2013

Accepted 22 Dec 2013

\begin{abstract}
Application of phosphate-solubilizing bacteria (PSB) has been shown to promote plant growth and development in the field and under controlled environmental conditions. The effects of PSB on microbial activity and soil quality are not well known. This study aims to determine the effect of inoculation with three PSB strains on the solubilization of rock phosphate (RP) in soil and growth promotion, nutrient uptake, photosynthetic capacity, and soil enzyme activities of 1-year-old walnut seedlings by using potted experiments with a completely randomized design under single or mixed inoculations. Inoculation with Pseudomonas aurantiaca or P. fluorescens significantly improved the plant height, shoot and root dry weight, phosphorus $(\mathrm{P})$ and nitrogen $(\mathrm{N})$ uptake, and net photosynthetic rate of walnut seedlings. Application of these two PSB strains also improved soil quality, as indicated by increased activities of dehydrogenase, neutral phosphatase, and urease in the soil. These increases were higher when PSB was applied together with RP. The most pronounced beneficial effects on plant growth and soil enzyme activities were observed when the three PSB strains were co-inoculated with RP. Bacillus cereus failed to promote plant growth. The results demonstrated that $P$. aurantiaca or $P$. fluorescens could be used as an environment-safe biofertilizer of walnut seedlings and other woody plants.
\end{abstract}

KEYWORDS: seedlings, enzyme activity, rhizosphere, biofertilizer

\section{INTRODUCTION}

After nitrogen $(\mathrm{N})$, phosphorus $(\mathrm{P})$ is the second major essential macronutrient for plant growth and development ${ }^{1}$. Although $\mathrm{P}$ is widely and abundantly distributed in the soil in both its inorganic and organic forms, many soils throughout the world are deficient of this nutrient ${ }^{2}$. Soils are usually supplemented with inorganic $\mathrm{P}$ in the form of chemical fertilizers. Plants can only utilize approximately $30 \%$ of phosphatic fertilizers that are often continuously applied; approximately $70 \%$ of these fertilizers are rapidly fixed into insoluble compounds, such as $\mathrm{Ca}_{3}\left(\mathrm{PO}_{4}\right)_{2}, \mathrm{AlPO}_{4}$, and iron phosphate in the soil ${ }^{3-5}$. Consequently, $\mathrm{P}$ is often regarded as a limiting nutrient in agricultural soils ${ }^{6}$. Hence, $\mathrm{P}$ fertilizers are often excessively applied to crop land to meet the $\mathrm{P}$ level required for plant growth and development. This unmanaged excess is not only costly but may also create environment problems ${ }^{7}$.

Excessive application of chemical fertilizers not only elicits negative environmental impacts but also incurs high costs. A previous research revealed that utilization of phosphate-solubilizing bacteria (PSB) is advantageous for sustainable agricultural practices ${ }^{8}$. PSB could convert these insoluble phosphates into forms available for plant use via acidification, chelation, exchange reactions, and gluconic acid secretion $^{9,10}$. In addition to their capacity for P-solubilization, PSB can also improve plant productivity by secreting other secondary metabolites, such as indole acetic acid ${ }^{11,12}$ and siderophore ${ }^{13}$. Numerous studies have focused on the effects of PSB on plant growth ${ }^{14-17}$. Little is known about the effects of PSB on microbial activity and soil quality ${ }^{18,19}$. This study aims to determine whether or not PSB inoculation improves rhizosphere environment.

In recent years, the ecosystem of the Yangtze River basin suffered from severe destruction and deterioration characterized by grassland degradation, soil erosion, and desertification. To mitigate or eliminate this predicament, the Chinese government executed a long-term project to convert 15 million acres of farmland to plantation forests within 15 years along the Yangtze River, especially in the regions of upper 
reaches ${ }^{20}$. Walnut is one of the major planting trees in China for both nut fruits and high-quality stemwood production. Walnut cropping or intercropping helps mitigate the problems of soil erosion and timber shortages in the Yangtze River basin; this operation requires a fair amount of $\mathrm{P}$ as the essential macronutrient for growth and development ${ }^{21}$. Studies therefore are being focused on P mobilization by PSB. The uptake of $\mathrm{P}$ by plants is beneficial to reduce the application of $\mathrm{P}$ fertilizers and to preserve environmental quality. To the best of our knowledge, limited reports related to the effect of PSB on the growth of walnut are available ${ }^{22}$, and studies on the beneficial effects of walnut with PSB inoculation on soil quality are lacking. The present study aims to evaluate the effects of PSB inoculation on P mobilization from rock phosphate (RP) and on diverse growth parameters, nutrient uptake, photosynthetic capacity of 1-year-old walnut seedlings and soil quality under shade house conditions.

\section{MATERIALS AND METHODS}

\section{Rock phosphate}

Rock phosphate was collected from the phosphate mine located in Mabian County, Southwest Sichuan Province, China. It was supplied as a 100-mesh-size fine powder containing $7 \%$ total $\mathrm{P}, 0.023 \mathrm{mg} / \mathrm{g}$ watersoluble $\mathrm{P}, 0.15 \mathrm{mg} / \mathrm{g} \mathrm{P}$ soluble in $0.5 \mathrm{M} \mathrm{NaHCO}_{3}$, and a pH of 8.1. Phosphorus in RP was presented as carbonate fluorapatite, which constituted approximately $72 \%$ of total RP, and was of sedimentary origin.

\section{Microbial culture and inoculants preparation}

The bacterial strains used in this study were originally isolated from rhizosphere of 10 -year-old walnut plants. And they were identified as P. aurantiaca, $B$. cereus, and $P$. fluorescens through a comparison of the 16S rDNA sequences ${ }^{22}$.

Stock cultures were stored at $-80{ }^{\circ} \mathrm{C}$ in $50 \%$ glycerol. All cultures were revived and subcultured before use in the present study. Inocula were prepared by incubating the bacterial strains in nutrient medium to mid-exponential growth phase followed by diluting in sterile distilled water to a final concentration $10^{9} \mathrm{CFU} / \mathrm{ml}$. The resulting suspensions were used to treat 1-year-old walnut seedlings (J. siggillata L.).

\section{Pot experiment}

A potted culture experiment was carried out in a shade house located at the forest nursery of Sichuan Agriculture University in Southwest China $\left(29^{\circ} 59^{\prime} \mathrm{N}\right.$ at an altitude of $620 \mathrm{~m}$ ). The complete growth period of walnut seedlings lasted from March to October 2008. Potting soil was taken from the breeding station of walnut in Yaan City, Sichuan Province. The soil was classified as sandy loam and had the following characteristics: $\mathrm{pH}, 7.1$; organic matter content, $10.43 \mathrm{~g} / \mathrm{kg}$; total N, $0.80 \mathrm{~g} / \mathrm{kg}$; total P, $0.34 \mathrm{~g} / \mathrm{kg}$; and available $P, 4.50 \mathrm{mg} / \mathrm{kg}$. One seedling was planted in each polyethylene pot $(25 \mathrm{~cm}$ diameter $\times 50 \mathrm{~cm}$ height) containing an unsterile mixture of soil/sand ( $2: 1$ in volume). The unsterilized soil mix was selected to represent field conditions. Basal doses of $\mathrm{N}$ $(300 \mathrm{mg} / \mathrm{kg}$ soil) and potassium $(\mathrm{K}, 200 \mathrm{mg} / \mathrm{kg}$ soil, calculated according to $\mathrm{K}_{2} \mathrm{O}$ ) fertilizers were applied in the form of urea and $\mathrm{KNO}_{3}$, respectively. RP was uniformly mixed with the potted soil to supply $200 \mathrm{mg}$ P per kg soil.

The experimental plan comprised the following 10 treatments: (1) control without RP (-RP) and without bacteria; (2) $(-\mathrm{RP})+P$. aurantiaca; (3) $(-\mathrm{RP})+$ P. fluorescens; (4) $(-\mathrm{RP})+$ B. cereus; (5) $(-\mathrm{RP})+$ mixture (P. aurantiaca + P. fluorescens + B. cereus, 1:1:1 in volume); (6) with RP addition only $(+\mathrm{RP}) ;(7)(+\mathrm{RP})+$ P. aurantiaca $;(8)(+\mathrm{RP})+$ P. fluorescens; (9) (+RP) + B. cereus; and (10) $(+\mathrm{RP})$ + mixture (P. aurantiaca + P. fluorescens $+B$. cereus, 1:1:1 in volume). The experiment was performed in a completely randomized design. Each treatment was replicated five times. All bacteria and their combination were applied through a syringe, with which $50 \mathrm{ml}$ of bacterial suspension was inoculated into the middle of seedling roots ${ }^{14}$. Control plants received $50 \mathrm{ml}$ of diluted nutrient medium with no bacteria. Walnut seedlings were watered daily to maintain the soil water content close to field capacity and to ensure that the water was not the limiting factor during the study period.

The seedlings were harvested after the growth period of plants. Growth promotion effects of bacterial treatments were assessed by measuring plant height, shoot and root weight, and $\mathrm{N}$ and $\mathrm{P}$ nutrient uptake of walnut plants.

\section{Nutrient analysis}

Plant samples were finely ground after drying at approximately $65^{\circ} \mathrm{C}$ for $48 \mathrm{~h}$. The ground samples were used to determine the $\mathrm{N}, \mathrm{P}$, and $\mathrm{K}$ concentrations of the walnut seedlings. P concentration was assayed, after digestion in nitric-perchloric acid (5:3 in volume) for $6 \mathrm{~h}$, by colorimetry ${ }^{23}$. K concentration was measured following a method described ${ }^{24}$. $\mathrm{N}$ concentration was determined by using the Kjeldahl digestion method according to the procedures described ${ }^{25}$. 
Table 1 Effect of inoculation with PSB on growth parameters and nutrient uptake of walnut seedlings ${ }^{\dagger}$

\begin{tabular}{|c|c|c|c|c|c|c|}
\hline Treatments & $\begin{array}{l}\text { Plant height } \\
\text { (cm) }\end{array}$ & $\begin{array}{l}\text { Shoot dry } \\
\text { weight }(g)\end{array}$ & $\begin{array}{c}\text { Root dry } \\
\text { weight }(\mathrm{g})\end{array}$ & $\begin{array}{l}\text { Total P uptake } \\
\quad(\mathrm{g} / \mathrm{kg})\end{array}$ & $\begin{array}{l}\text { Total N uptake } \\
(\mathrm{g} / \mathrm{kg})\end{array}$ & $\begin{array}{c}\text { Total K uptake } \\
(\mathrm{g} / \mathrm{kg})\end{array}$ \\
\hline Soil only (-RP) & $27.2^{\mathrm{d}}$ & $5.3^{\mathrm{e}}$ & $4.7^{\mathrm{g}}$ & $3.20^{\mathrm{e}}$ & $22.70^{f}$ & $28.70^{\mathrm{e}}$ \\
\hline$(-\mathrm{RP})+P$. aurantiaca & $31.9^{\mathrm{c}}$ & $6.4^{\mathrm{c}}$ & $6.3^{\mathrm{d}}$ & $4.13^{c}$ & $26.26^{\mathrm{cd}}$ & $31.07^{\mathrm{abcd}}$ \\
\hline$(-\mathrm{RP})+$ P. fluorescens & $31.5^{\mathrm{c}}$ & $5.8^{\mathrm{d}}$ & $5.7^{\mathrm{f}}$ & $3.84^{\mathrm{d}}$ & $25.49^{\mathrm{de}}$ & $29.66^{\text {bcde }}$ \\
\hline$(-\mathrm{RP})+$ B. cereus & $27.7^{\mathrm{d}}$ & $5.4^{\mathrm{e}}$ & $4.8^{\mathrm{g}}$ & $3.28^{\mathrm{e}}$ & $23.48^{\text {ef }}$ & $29.35^{\mathrm{de}}$ \\
\hline$(-\mathrm{RP})+(P .+P .+B .)^{*}$ & $34.3^{\mathrm{b}}$ & $6.9^{\mathrm{b}}$ & $7.0^{\mathrm{b}}$ & $4.42^{\mathrm{b}}$ & $29.16^{\mathrm{b}}$ & $31.28^{\mathrm{abc}}$ \\
\hline With RP addition $(+\mathrm{RP})$ & $28.0^{\mathrm{d}}$ & $5.4^{\mathrm{e}}$ & $4.9^{g}$ & $3.23^{\mathrm{e}}$ & $23.45^{\mathrm{ef}}$ & $29.52^{\text {bcde }}$ \\
\hline$(+\mathrm{RP})+P$. aurantiaca & $34.0^{\mathrm{b}}$ & $7.0^{\mathrm{b}}$ & $6.7^{\mathrm{c}}$ & $4.42^{\mathrm{b}}$ & $29.17^{b}$ & $32.51^{\mathrm{a}}$ \\
\hline$(+\mathrm{RP})+$ P. fluorescens & $33.6^{\mathrm{b}}$ & $6.5^{\mathrm{c}}$ & $6.0^{\mathrm{e}}$ & $4.16^{\mathrm{c}}$ & $28.67^{\text {bc }}$ & $31.48^{\mathrm{ab}}$ \\
\hline$(+\mathrm{RP})+$ B. cereus & $28.2^{\mathrm{d}}$ & $5.5^{\mathrm{e}}$ & $4.9^{\mathrm{g}}$ & $3.31^{\mathrm{e}}$ & $23.68^{\mathrm{def}}$ & $30.01^{\text {bcde }}$ \\
\hline$(+\mathrm{RP})+(P .+P .+B .)^{*}$ & $37.1^{\mathrm{a}}$ & $7.5^{\mathrm{a}}$ & $7.2^{\mathrm{a}}$ & $4.72^{\mathrm{a}}$ & $32.72^{\mathrm{a}}$ & $33.18^{\mathrm{a}}$ \\
\hline
\end{tabular}

$\dagger$ Values are the means of five replicates. Within columns, significant differences according to Fisher's protected LSD test at the $p \leqslant 0.05$ level are indicated by different letters.

${ }^{*}$ P. aurantiaca + P. fluorescens + B. cereus

\section{Soil analysis}

Rhizosphere soil samples were aseptically separated from roots to test chemical properties. Soil $\mathrm{pH}$ was determined in a 2:1 water/soil suspension by a $\mathrm{pH}$ meter. Available $\mathrm{P}$ was extracted by the bicarbonate method and analysed by the molybdate blue method ${ }^{26}$.

\section{Determination of bacterial population}

Enumeration of soil bacterial population was carried out using the suspension-dilution technique on agar plates with selective media. The total heterotrophic bacterial populations were counted on nutrient broth (Difco Laboratories, Detroit, Michigan, USA) amended with $15 \mathrm{~g} / \mathrm{l}$ agar. The tricalcium phosphate medium ${ }^{27}$ was used for PSB bacteria determination.

\section{Enzyme activities measurement}

The activities of soil dehydrogenase, phosphatase, and urease were determined according to the methods described by García et $\mathrm{al}^{28}$, Kandeler et $\mathrm{al}^{29}$, and Nannipieri et $\mathrm{al}^{30}$, respectively.

\section{Photosynthetic capacity analysis}

Before harvest, the net photosynthetic rate (Pn) and transpiration rate $(\mathrm{Tr})$ of the seedlings were determined with a portable photosynthesis system (Model LI-6400, USA). The instantaneous water use efficiency (WUE) of the seedlings was calculated according to the photosynthetic parameters. The parameters were measured on the uppermost, fully expanded leaves of each plant from 09:00 AM to 11:00 AM under bright sunlight on a clear, cloudless day. Five replications were prepared for each plant at each time.

\section{Statistical analysis}

The data collected in this study were subjected to ANOVA and comparisons between treatments means were separated by Fisher's protected LSD test. The SPSS package (version 11.0) was used for statistical analyses. Differences were considered significant at $p \leqslant 0.05$.

\section{RESULTS}

\section{Plant growth and nutrient uptake of walnut seedlings}

The effect of inoculation with PSB strains on the growth parameters and nutrient uptake of walnut seedlings is presented in Table 1. Inoculation with $P$. aurantiaca or $P$. fluorescens significantly $(p \leqslant 0.05)$ enhanced the plant height and shoot, as well as the root dry weight of walnut seedlings compared with those of the control plants. The PSB strain B. cereus failed to promote plant growth in inoculated soils. Co-inoculation with the three PSB strains resulted in maximum plant height, shoot and root dry weight than when these organisms were used alone. In relation to RP application, no significant differences were observed between individual RP application and without RP supplement. The effect of two-factor interaction of RP with $P$. aurantiaca, $P$. fluorescens, or the mixture of the three PSB strains was significant with respect to both plant height and dry weight. Co-inoculation with $P$. aurantiaca, $P$. fluorescens, and B. cereus in the presence of RP showed the most pronounced effects.

The total P and $\mathrm{N}$ uptake of the plants inoculated with $P$. aurantiaca or $P$. fluorescens were remarkably increased compared with those of the control plants. In contrast, $B$. cereus inoculation failed to signifi- 
Table 2 Effect of inoculation with PSB on $\mathrm{pH}$, available phosphorus concentration, and total populations of PSB and heterotrophic bacteria in the rhizosphere of walnut seedlings!

\begin{tabular}{|c|c|c|c|c|}
\hline Treatments & $\mathrm{pH}$ & $\begin{array}{l}\text { Available P } \\
\text { (mg/kg soil) }\end{array}$ & $\begin{array}{c}\text { PSB } \\
\text { (CFU/g soil) }\end{array}$ & $\begin{array}{l}\text { Heterotrophic bacteria } \\
\text { (CFU/g soil) }\end{array}$ \\
\hline Soil only $(-\mathrm{RP})$ & $7.76^{\mathrm{a}}$ & $7.60^{\mathrm{e}}$ & $4.62^{\mathrm{d}}$ & $6.28^{\mathrm{f}}$ \\
\hline$(-\mathrm{RP})+P$ aurantiaca & $7.38^{\mathrm{c}}$ & $9.92^{\mathrm{cd}}$ & $5.22^{\mathrm{c}}$ & $7.33^{\mathrm{d}}$ \\
\hline$(-\mathrm{RP})+$ P. fluorescens & $7.45^{\mathrm{bc}}$ & $9.81^{\mathrm{d}}$ & $5.13^{\mathrm{c}}$ & $7.11^{\mathrm{e}}$ \\
\hline$(-\mathrm{RP})+$ B. cereus & $7.69^{\mathrm{a}}$ & $7.67^{\mathrm{e}}$ & $4.74^{\mathrm{d}}$ & $6.35^{\mathrm{f}}$ \\
\hline$(-\mathrm{RP})+(P .+P .+B .)^{*}$ & $7.29^{\mathrm{cd}}$ & $10.25^{\mathrm{b}}$ & $5.60^{\mathrm{b}}$ & $7.84^{\mathrm{b}}$ \\
\hline With $\mathrm{RP}$ addition $(+\mathrm{RP})$ & $7.63^{\mathrm{a}}$ & $7.71^{\mathrm{e}}$ & $4.68^{\mathrm{d}}$ & $6.40^{\mathrm{f}}$ \\
\hline$(+\mathrm{RP})+P$. aurantiaca & $7.06^{\mathrm{e}}$ & $10.27^{\mathrm{b}}$ & $5.55^{\mathrm{b}}$ & $7.63^{\mathrm{c}}$ \\
\hline$(+\mathrm{RP})+$ P. fluorescens & $7.16^{\mathrm{de}}$ & $10.12^{\mathrm{bc}}$ & $5.48^{\mathrm{b}}$ & $7.42^{\mathrm{d}}$ \\
\hline$(+\mathrm{RP})+$ B. cereus & $7.63^{\mathrm{a}}$ & $7.74^{\mathrm{e}}$ & $4.78^{\mathrm{d}}$ & $6.43^{\mathrm{f}}$ \\
\hline$(+\mathrm{RP})+(P .+P .+B .)^{*}$ & $6.86^{\mathrm{f}}$ & $10.60^{\mathrm{a}}$ & $5.94^{\mathrm{a}}$ & $8.18^{\mathrm{a}}$ \\
\hline
\end{tabular}

$\dagger$ Values are the means of five replicates. Within columns, significant differences according to Fisher's protected LSD test at the $p \leqslant 0.05$ level are indicated by different letters.

${ }^{*}$ P. aurantiaca + P. fluorescens + B. cereus

cantly increase total $\mathrm{P}$ and $\mathrm{N}$ uptake. The addition of insoluble phosphate to the inoculated soil with $P$. aurantiaca or $P$. fluorescens significantly increased the uptake of both $\mathrm{P}$ and N. Co-inoculation with the three PSB strains further improved $\mathrm{P}$ and $\mathrm{N}$ uptake compared with single PSB inoculation. Furthermore, co-inoculation with the three PSB strains and RP amendment resulted in the highest $\mathrm{P}$ and $\mathrm{N}$ uptake of walnut seedlings. The $\mathrm{K}$ content per plant in walnut seedlings increased significantly in soils inoculated with $P$. aurantiaca $(p \leqslant 0.05)$ regardless of whether or not RP was added. Nevertheless, neither $P$. fluorescens nor $B$. cereus tested improved the uptake of K. No significant interaction was observed between PSB inoculation and insoluble phosphate in terms of the $\mathrm{K}$ content of experimental walnut seedlings.

\section{Changes in pH, available $P$, and bacterial population in the rhizosphere of walnut}

The effect of inoculation with PSB strains on soil $\mathrm{pH}$, available $\mathrm{P}$ concentration, and total population of heterotrophic bacteria and PSB in the rhizosphere of walnut seedlings is presented in Table 2. Inoculation with $P$. aurantiaca or $P$. fluorescens significantly $(p \leqslant 0.05)$ decreased soil $\mathrm{pH}$ and increased the concentration of soil available $\mathrm{P}$ compared to the control soil, whereas inoculation with $B$. cereus had no effect on soil $\mathrm{pH}$ and available $\mathrm{P}$. Co-inoculation with the three PSB strains further decreased soil $\mathrm{pH}$ and increased available P. The application of RP in combination with $P$. aurantiaca or $P$. fluorescens significantly decreased soil $\mathrm{pH}$ values and increased the concentration of soil available $\mathrm{P}$ compared with the application of PSB without RP addition. Mixed inoculation with the three PSB strains in the presence of RP resulted in the highest available $P$ and the lowest $\mathrm{pH}$ in soils than when these organisms were used alone.

The populations of total heterotrophic bacteria and PSB in the rhizosphere of walnut seedlings significantly increased $(p \leqslant 0.05)$ after inoculation with $P$. aurantiaca or $P$. fluorescens. Moreover, the addition of RP further stimulated the growth of total heterotrophic bacterial and PSB populations. Co-inoculation with the three PSB strains increased the populations of total heterotrophic bacteria and PSB than when these organisms were applied alone. Similarly, coinoculation with $P$. aurantiaca, $P$. fluorescens, and $B$. cereus in the presence of RP showed the most pronounced effects.

\section{Enzyme activities in the rhizosphere of walnut}

The effect of inoculation with PSB strains on the activities of dehydrogenase, phosphatase, and urease in the rhizosphere of walnut seedlings is presented in Table 3. Inoculation with $P$. aurantiaca or $P$. $f l u$ orescens significantly $(p \leqslant 0.05)$ improved the activities of dehydrogenase, neutral phosphatase, and urease activities in the rhizosphere compared with the control. B. cereus had no effect on the activities of the three soil enzymes in the rhizosphere of walnut seedlings. Furthermore, mixed inoculation with the three PSB strains led to the maximum activities of dehydrogenase, neutral phosphatase, and urease than when these organisms were used alone. The addition of RP individually into the soil only slightly increased the activities of the three enzymes compared with the control. Nevertheless, the synergistic effect of two 
Table 3 Effect of inoculation with PSB on the activities of dehydrogenase, neutral phosphatase, and urease in the rhizosphere of walnut seedlings. ${ }^{\dagger}$

\begin{tabular}{|c|c|c|c|}
\hline Treatments & $\begin{array}{l}\text { Dehydro- } \\
\text { genase } \\
\text { ( } \mu \text { g INTF } \\
\text { per g soil) }\end{array}$ & $\begin{array}{c}\text { Neutral } \\
\text { phosphatase } \\
\left(\mathrm{mg} \mathrm{P}_{2} \mathrm{O}_{5} \text { per }\right. \\
\mathrm{g} \text { soil in } 24 \mathrm{~h})\end{array}$ & $\begin{array}{c}\text { Urease } \\
\text { (mg NH} H_{3}-\mathrm{N} \\
\text { per g soil } \\
\text { in } 24 \mathrm{~h})\end{array}$ \\
\hline $\begin{array}{l}\text { Soil only }(-\mathrm{RP}) \\
(-\mathrm{RP})+\text { P. aurantiaca } \\
(-\mathrm{RP})+\text { P. fuorescens } \\
(-\mathrm{RP})+\text { B. cereus } \\
(-\mathrm{RP})+(P .+P .+B .) \\
\text { With RP addition }(+\mathrm{RP}) \\
(+\mathrm{RP})+\text { P. aurantiaca } \\
(+\mathrm{RP})+\text { P. fuorescens } \\
(+\mathrm{RP})+\text { B. cereus } \\
(+\mathrm{RP})+(P .+P .+B .)\end{array}$ & $\begin{array}{l}38^{\mathrm{d}} \\
43^{\mathrm{c}} \\
42^{\mathrm{c}} \\
39^{\mathrm{d}} \\
46^{\mathrm{b}} \\
40^{\mathrm{cd}} \\
46^{\mathrm{b}} \\
45^{\mathrm{b}} \\
41^{\mathrm{cd}} \\
49^{\mathrm{a}}\end{array}$ & $\begin{array}{l}0.26^{\mathrm{d}} \\
0.63^{\mathrm{c}} \\
0.56^{\mathrm{c}} \\
0.33^{\mathrm{d}} \\
0.94^{\mathrm{b}} \\
0.37^{\mathrm{d}} \\
0.97^{\mathrm{b}} \\
0.96^{\mathrm{b}} \\
0.38^{\mathrm{d}} \\
1.26^{\mathrm{a}}\end{array}$ & $\begin{array}{l}0.47^{\mathrm{e}} \\
0.83^{\mathrm{c}} \\
0.77^{\mathrm{cd}} \\
0.53^{\mathrm{e}} \\
1.14^{\mathrm{b}} \\
0.61^{\mathrm{de}} \\
1.20^{\mathrm{b}} \\
1.12^{\mathrm{b}} \\
0.62^{\mathrm{de}} \\
1.45^{\mathrm{a}}\end{array}$ \\
\hline
\end{tabular}

$\dagger$ Values are the means of five replicates. Within columns, significant differences according to Fisher's protected LSD test at the $p \leqslant 0.05$ level are indicated by different letters.

* P. aurantiaca + P. fluorescens + B. cereus

Table 4 Effect of inoculation with PSB on the net photosynthetic rate, transpiration rate and instantaneous water use efficiency of walnut seedlings. ${ }^{\dagger}$

\begin{tabular}{|c|c|c|c|}
\hline Treatments & $\begin{array}{c}\mathrm{Pn} \\
\left(\mu \mathrm{mol} \mathrm{m} \mathrm{m}^{-2} \mathrm{~s}^{-1}\right)\end{array}$ & 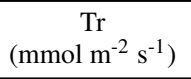 & WUE \\
\hline $\begin{array}{l}\text { Soil only }(-\mathrm{RP}) \\
(-\mathrm{RP})+\text { P. aurantiaca } \\
(-\mathrm{RP})+\text { P. fluorescens } \\
(-\mathrm{RP})+\text { B. cereus } \\
(-\mathrm{RP})+(P .+P .+B .)^{*} \\
\text { With RP addition }(+\mathrm{RP}) \\
(+\mathrm{RP})+P . \text { aurantiaca } \\
(+\mathrm{RP})+P . \text { fluorescens } \\
(+\mathrm{RP})+\text { B. cereus } \\
(+\mathrm{RP})+(P .+P .+B .)\end{array}$ & $\begin{array}{l}3.4^{\mathrm{f}} \\
4.51^{\mathrm{de}} \\
4.18^{\mathrm{e}} \\
3.61^{\mathrm{f}} \\
5.03^{\mathrm{b}} \\
3.67^{\mathrm{f}} \\
4.96^{\mathrm{bc}} \\
4.60^{\mathrm{cd}} \\
3.69^{\mathrm{f}} \\
5.47^{\mathrm{a}}\end{array}$ & $\begin{array}{l}1.86^{\mathrm{d}} \\
2.20^{\mathrm{abc}} \\
2.17^{\mathrm{abc}} \\
1.93^{\mathrm{cd}} \\
2.23^{\mathrm{ab}} \\
1.96^{\mathrm{bcd}} \\
2.29^{\mathrm{a}} \\
2.28^{\mathrm{a}} \\
1.94^{\mathrm{cd}} \\
2.31^{\mathrm{a}}\end{array}$ & $\begin{array}{l}1.85^{\mathrm{c}} \\
2.05^{\mathrm{bc}} \\
1.94^{\mathrm{bc}} \\
1.87^{\mathrm{c}} \\
2.32^{\mathrm{a}} \\
1.88^{\mathrm{c}} \\
2.17^{\mathrm{ab}} \\
2.02^{\mathrm{bc}} \\
1.91^{\mathrm{c}} \\
2.37^{\mathrm{a}}\end{array}$ \\
\hline
\end{tabular}

$\dagger$ Values are the means of five replicates. Within columns, significant differences according to Fisher's protected LSD test at the $p \leqslant 0.05$ level are indicated by different letters.

${ }^{*}$ P. aurantiaca + P. fluorescens + B. cereus

factors of RP and P. aurantiaca, P. fluorescens, or the mixture of the three PSB strains on the activities of the three soil enzymes was significant. The most pronounced beneficial effects on soil enzyme activities were observed when the three PSB strains were coinoculated with RP.

\section{Effect of PSB inoculation on the photosynthetic capacity of walnut seedlings}

The effect of inoculation with PSB strains on Pn, $\mathrm{Tr}$, and WUE of the walnut seedlings is presented in Table 4. Single inoculation of $P$. aurantiaca or $P$. fluorescens significantly $(p \leqslant 0.05)$ enhanced the Pn value of the experimental seedlings compared with the control. B. cereus inoculation did not promote the
Pn of the walnut seedlings. The application of RP in combination with $P$. aurantiaca or $P$. fluorescens obviously $(p \leqslant 0.05)$ increased Pn compared to the application of the organisms alone. Co-inoculation with the three PSB strains further improved Pn when compared with single PSB inoculation. The highest results were obtained when the three PSB strains and insoluble phosphate was applied together. The $\mathrm{Tr}$ of the walnut seedlings significantly increased $(p \leqslant 0.05)$ in the soils inoculated with $P$. aurantiaca, $P$. fluorescens, or the mixture of the three PSB strains. $B$. cereus failed to improve the $\operatorname{Tr}$ of experimental seedlings. Furthermore, no significant interaction was observed between PSB inoculation and insoluble phosphate on the $\operatorname{Tr}$ of the walnut seedlings. The WUE of the walnut seedlings significantly increased $(p \leqslant 0.05)$ after inoculation with the mixture of the three PSB strains. Similarly, no significant synergistic effect between PSB inoculation and insoluble phosphate on the WUE of the experimental walnut seedlings was observed.

\section{DISCUSSION}

The significant increase in the height and dry weight of walnut seedlings due to inoculation with $P$. $a u$ rantiaca or $P$. fluorescens could be attributed to an enhanced absorption of nutrients, particularly P. The present results were similar to those reported for growth chamber and greenhouse experiments. Some researchers have obtained opposite conclusions when PSB were inoculated into different soil types or plants. Selvaraj et al ${ }^{11}$ observed that seed bacterization with PSB strains increases the root elongation and biomass of Chinese cabbage in seedling culture but did not affect the P uptake. Hence PSB could stimulate plant growth through mechanisms other than $\mathrm{P}$ uptake.

The increased plant height, dry weight, and $\mathrm{P}$ and $\mathrm{N}$ uptake of the walnut seedlings after the addition of RP in inoculated soils may also be attributed to an increased populations of PSB and possibly to an indirect increase in the total native microbial populations resulting from altered root exudation. The addition of RP to the inoculated soil increased the total soil populations of PSB. Thus the addition of RP supports the proliferation and possibly the survival of the tested PSB by providing a substrate for these isolates. The plant response to the treatments with RP may be attributed to the activity and interaction with the indigenous phosphate-solubilizing microflora in the soil. Hence, a higher content of available $P$ would be released into the soil and utilized by the plants.

The use of soil biological markers related to microbial activity, such as enzyme activities, has been 
proposed by Naseby and Lynch ${ }^{31}$. Dehydrogenase is involved in oxidative processes in soils, and its activity mainly depends on the metabolic state of soil biota. Thus dehydrogenase activity is considered a good indicator of soil microbial activity ${ }^{28}$. The increase in microbial activity is indicated by the increase in dehydrogenase activity in the rhizosphere of inoculated plants. Phosphatase and urease activities reflect the capacity of a soil to mineralize organic $\mathrm{N}$ and $\mathrm{P}$ compounds ${ }^{32,33}$. Since acid phosphatase and alkaline phosphatase are predominant in acid and alkaline soils ${ }^{34}$, respectively, we only determined the neutral phosphatase activity because the experimental soil had $\mathrm{pH}$ 7.1. In the present study, microbial inoculation promoted the activities of neutral phosphatase, urease, and dehydrogenase in the rhizosphere. The increments observed in enzyme activities may be related to an overall increase in the rhizosphere microbial populations as a consequence of the inoculation treatments. In addition, PSB application improved soil quality and thus enhanced the nutrient uptake and growth of the plants.

Co-inoculation of the three PSB strains improved the plant height, dry weight, and $\mathrm{P}$ and $\mathrm{N}$ uptake of the walnut seedlings as compared with individual inoculations, indicating that the three PSB strains can act synergistically during plant growth and development. Mixed inoculation with the PSB strain Bacillus sp. and the NFB strain Mesorhizobium sp. significantly increased the nodulation, yield, foliage chlorophyll content, and $\mathrm{N}$ uptake of chickpea (Cicer arietinum L.) compared with single inoculation with either PSB or $\mathrm{NFB}^{35}$. Afzal and Bano ${ }^{36}$ reported that the yield of various crops increases after seed or soil inoculation with phosphate-solubilizing organisms and other plant growth-promoting rhizobacteria. Similarly, inoculation with phosphate-solubilizing B. megaterium, $\mathrm{N}_{2}$-fixing B. subtilis, and Rhizobium leguminosarum bv. phaseoli significantly improves seed yield, with a concomitant increase in the uptake of macronutrients and micronutrients by the common bean ${ }^{37}$. The improvement in growth and yield parameters of various plants by combined inoculation of PSB and other microorganisms may be attributed to the following reasons. First, PSB can alter the composition of root secretion and plasticity, which in turn may influence the colonization and development of each other. Second, the growth-promoting substances produced by these organisms affect the root morphology and thus provide a more balanced nutrition for plants from soil. Last, the interactions between PSB and other microorganisms can cause a synergistic effect that allows for the exploitation of poorly soluble $\mathrm{P}$ sources. Further studies should focus on the detailed mechanisms accounting for the synergistic effect to clarify the biochemical basis of these interactions.

Acknowledgements: This study was supported by State Natural Science \& Technology Resources Share Base of China (2005DKA21207-13). We thank Wanbo Wu and Huabai Han for providing experimental walnut seedlings.

\section{REFERENCES}

1. Vance CP (2001) Symbiotic nitrogen fixation and phosphorus acquisition. Plant nutrition in a world of declining renewable resources. Plant Physiol 127, 390-7.

2. Wang GH, Jin J, Xu MN, Pan XW, Tang C (2007) Inoculation with phosphate-solubilizing fungi diversifies the bacterial community in rhizospheres of maize and soybean. Pedosphere 17, 191-9.

3. Vassilev N, Vassileva M (2003) Biotechnological solubization of rock phosphate on media containing agro-industrial wastes. Appl Microbiol Biotechnol 61, 435-40.

4. Alam MM, Ladha JK (2004) Optimizing phosphorus fertilization in an intensive vegetable-rice cropping system. Biol Fertil Soils 40, 277-83.

5. Tao GC, Tian SJ, Cai MY, Xie GH (2008) Phosphatesolubilizing and -mineralizing abilities of bacteria isolated from soils. Pedosphere 18, 515-23.

6. Guiñazú LB, Andrés JA, Del Papa MF, Pistorio M, Rosas SB (2010) Response of alfalfa (Medicago sativa L.) to single and mixed inoculation with phosphatesolubilizing bacteria and Sinorhizobium meliloti. Biol Fertil Soils 46, 185-90.

7. Kang S-M, Hamayun M, Joo G-J, Khan AL, Kim Y-H, Kim S-K, Jeong H-J, Lee I-J (2010) Effect of Burkholderia sp. KCTC 11096BP on some physiochemical attributes of cucumber. Eur J Soil Biol 46, 264-8.

8. Gyaneshwar P, Naresh Kumar G, Parekh LJ, Poole PS (2002) Role of soil microorganisms in improving $P$ nutrition of plants. Plant Soil 245, 83-93.

9. Chung H, Park M, Madhaiyan M, Seshadri S, Song J, Cho H, Sa T (2005) Isolation and characterization of phosphate solubilizing bacteria from the rhizosphere of crop plants of Korea. Soil Biol Biochem 37, 1970-4.

10. Gulati A, Sharma N, Vyas P, Sood S, Rahi P, Pathania V, Prasad R (2010) Organic acid production and plant growth promotion as a function of phosphate solubilization by Acinetobacter rhizosphaerae strain BIHB 723 isolated from the cold deserts of the transHimalayas. Arch Microbiol 192, 975-83.

11. Poonguzhali S, Madhaiyan M, Sa T (2008) Isolation and identification of phosphate solubilizing bacteria from Chinese cabbage and their effect on growth and phosphorus utilization of plants. J Microbiol Biotechnol 18, 773-7.

12. Shahab S, Ahmed N, Khan NS (2009) Indole acetic 
acid production and enhanced plant growth promotion by indigenous PSBs. Afr J Agr Res 4, 1312-6.

13. Koo S-Y, Cho K-S (2009) Isolation and characterization of a plant growth-promoting rhizobacterium, Serratia sp. SY5. J Microbiol Biotechnol 19, 1431-8.

14. Aslantas R, Cakmakci R, Sahin F (2007) Effect of plant growth promoting rhizobacteria on young apple tree growth and fruit yield under orchard conditions. Sci Hort 111, 371-7.

15. Hameeda B, Harini G, Rupela OP, Wani SP, Reddy $\mathrm{G}$ (2008) Growth promotion of maize by phosphatesolubilizing bacteria isolated from composts and macrofauna. Microbiol Res 163, 234-42.

16. Akhtar MS, Siddiqui ZA (2009) Effects of phosphate solubilizing microorganisms and Rhizobium sp. on the growth, nodulation, yield and root-rot disease complex of chickpea under field condition. Afr J Biotechnol $\mathbf{8}$, 3489-96.

17. Taurian T, Anzuay MS, Angelini JG, Tonelli ML, Ludueña L, Pena D, Ibáñez F, Fabra A (2010) Phosphatesolubilizing peanut associated bacteria: screening for plant growth-promoting activities. Plant Soil 329, 421-31.

18. Kim KY, Jordan D, McDonald GA (1998) Effect of phosphate-solubilizing bacteria and vesicular-arbuscular mycorrhizae on tomato growth and soil microbial activity. Biol Fertil Soils 26, 79-87.

19. Mader P, Kaiser F, Adholeya A, Singh R, Uppal HS, Sharma AK, Srivastava R, Sahai V, Aragno M, Wiemken A, Johri BN, Fried PM (2011) Inoculation of root microorganisms for sustainable wheat-rice and wheat-black gram rotations in India. Soil Biol Biochem 43, 609-19.

20. Zhang PC, Shao GF, Zha G, Le Master DC, Parker GR, Dunning JB, Li QL (2000) China's forest policy for 21st century. Science 288, 2135-6.

21. Peng JB (1989) Pomiculture. Chinese Agric Press, Beijing.

22. Yu X, Liu X, Zhu TH, Liu GH, Mao C (2011) Isolation and characterization of phosphate-solubilizing bacteria from walnut and their effect on growth and phosphorus mobilization. Biol Fertil Soils 47, 437-46.

23. Murphy J, Riley JP (1962) A modified single solution method for the determination of phosphate in natural waters. Anal Chim Acta 27, 31-6.

24. Jakson ML (1973) Soil Chemical Analysis. Prentice Hall India Pvt. Ltd, New Delhi.

25. Basak BB, Biswas DR (2010) Co-inoculation of potassium solubilizing and nitrogen fixing bacteria on solubilization of waste mica and their effect on growth promotion and nutrient acquisition by a forage crop. Biol Fertil Soils 46, 641-8.

26. Colwell JD (1965) An automatic procedure for the determination of phosphorus in sodium hydrogen carbonate extracts of soils. Chem Ind 22, 893-5.

27. Pikovskaya RI (1948) Mobilization of phosphorus in soil in connection with vital activity of some microbial species. Microbiologiya 17, 362-70.

28. García C, Hernandez MT, Costa F (1997) Potential use of dehydrogenase activity as an index of microbial activity in degraded soils. Comm Soil Sci Plant Anal 28, 123-34.

29. Kandeler E, Tscherko D, Spiegel H (1999) Long-term monitoring of microbial biomass, $\mathrm{N}$ mineralization and enzyme activities of a Chernozem under different tillage management. Biol Fertil Soils 28, 343-51.

30. Nannipieri P, Ceccanti B, Cervelli S, Matarese E (1980) Extraction of phosphatase, urease, proteases, organic carbon, and nitrogen from soil. Soil Sci Soc Am J 44, 1011-6.

31. Naseby DC, Lynch JM (1997) Rhizosphere soil enzymes as indicators of perturbations caused by enzyme substrate addition and inoculation of a genetically modified strain of Pseudomonas fluorescens on wheat seed. Soil Biol Biochem 29, 1353-62.

32. Maeder P, Fliessbach A, Dubois D, Gunst L, Fried P, Niggli U (2002) Soil fertility and biodiversity in organic farming. Science 296, 1694-7.

33. Kohler J, Caravaca F, Carrasco L, Roldán A (2007) Interactions between a plant growth-promoting rhizobacterium, an AM fungus and a phosphate-solubilizing fungus in the rhizosphere of Lactuca sativa. Appl Soil Ecol 35, 480-7.

34. Eivazi F, Tabatabai MA (1977) Phosphatases in soils. Soil Biol Biochem 9, 167-72.

35. Wani PA, Khan MS, Zaidi A (2007) Co-inoculation of nitrogen-fixing and phosphate-solubilizing bacteria to promote growth, yield and nutrient uptake in chickpea. Acta Agron Hung 55, 315-23.

36. Afzal A, Bano A (2008) Rhizobium and phosphate solubilizing bacteria improve the yield and phosphorus uptake in wheat (Triticum aestivum). Int J Agr Biol 10, 85-8.

37. Elkoca E, Turan M, Donmez MF (2010) Effects of single, dual and triple inoculations with Bacillus subtilis, Bacillus megaterium and Rhizobium leguminosarum bv. phaseoli on nodulation, nutrient uptake, yield and yield parameters of common bean (Phaseolus vulgaris L. cv. 'Elkoca-05'). J Plant Nutr 33, 2104-19. 